\title{
EFFECT OF ADRENERGIC BETA-RECEPTOR BLOCKER ON EPINEPHRINE-INDUCED CARDIAC ARRHYTHMIAS DURING HALOTHANE ANAESTHESIA
}

\author{
LEonard T. TE, M.D., D.A.(TOR.), AND A. W. ConN, M.D., F.R.C.P.(c) ${ }^{\circ}$
}

\section{INTRODUCTION}

REsULTS OF INVESTIGations performed on animals indicate that halothane anaesthesia increases the sensitivity of the myocardial tissues to epinephrine. ${ }^{1-3}$ In man, ventricular arrhythmias may follow the use of the epinephrine. ${ }^{4-7}$ This investigation was undertaken to study the usefulness of an adrenergic $\beta$-receptor blocking agent (Pronethalol) $f$ in preventing and/or correcting cardiac arrhythmias produced by epinephrine infusion during halothane anaesthesia.

\section{METHOD OF STUDY}

After numerous trial studies, the following method was evolved: A total of eleven healthy mongrel dogs weighing 13 to $19 \mathrm{~kg}$. were studied. On the day of the experiment, the fasting dog received atropine $0.04 \mathrm{mg} . / \mathrm{kg}$. body weight intravenously immediately prior to induction. A "sleep" dose of thiopentone was then administered to produce hypnosis and to facilitate tracheal intubation with a cuffed Magill tube. Endotracheal anaesthesia was instituted using a Magill circuit and Stephen-Slater valve. Respiration was spontaneous and anaesthesia was maintained throughout the experiment with 1 per cent halothane and nitrous oxide-oxygen at a total flow of eight liters per minute. Anaesthesia was stabilized for 45 to 60 minutes prior to commencement of the first experiment.

An intravenous infusion of 5 per cent glucose in water was started and maintained through a percutaneously placed indwelling Rochester needle in one of the foreleg veins. A freshly prepared solution of 1:200,000 epinephrine in normal saline was connected to the intravenous set through a 3-way stopcock.

E.C.G. leads were properly placed and lead II tracings were observed continuously on the oscilloscope. Recordings were made at appropriate times. Intraarterial blood pressure was obtained by a percutaneously placed Rochester needle in the femoral artery and monitored through a Sanborn pressure transducer and recorder (Model 267B and Sanborn four-channel recorder).

Arterial blood samples were taken from the femoral artery immediately prior to each epinephrine infusion. These samples were analysed for $\mathrm{pH}$, carbon dioxide and oxygen tensions, using the Instrumentation Laboratory Machine. Any acid-base imbalance present in each examination was not corrected. Three epinephrine infusions were administered to each dog with half-hour intervals between each experiment.

-Dr. Te is Research Fellow in Anaesthesia, Research Institute, the Hospital Sick Children. Dr. Conn is Chief of Anaesthesia, the Hospital For Sick Children, Toronto.

†Provided through the courtesy of Ayerst, McKenna \& Harrison, Montreal. 


\section{Prockdure (EpRnephrmene Infusion)}

\section{First Experiment}

The purpose of the first experiment was to verify that ventricular arrhythmias could be produced and maintained by epinephrine infusion.

After all the preliminary preparations were accomplished, the epinephrine solution was administered by intravenous drip as rapidly as possible. The time intervals were recorded from the start of infusion to the onset of arrhythmias. The infusion was then maintained for exactly two minutes to observe if arrhythmias would persist; then it was discontinued. The time interval was again recorded from the moment epinephrine was stopped to the moment when arrhythmias spontaneously reversed to sinus rhythm. If, however, ventricular fibrillation supervened (as it did four times), resuscitative measures only were carried out. This experiment allowed each dog to serve as its own control.

\section{Second Experiment}

The purpose of the second experiment was to study the possible corrective action of pronethalol on epinephrine-induced ventricular arrhythmias.

After the first experiment, one half hour was allowed to elapse. The second experiment was commenced in the same manner as the first. With the onset of any type of ventricular arrhythmia, two milligrams of pronethalol were instantly administered intravenously without discontinuing the epinephrine infusion. The time interval required for the disappearance of arrhythmia was again recorded using the Sanborn recorder.

\section{Third Experiment}

The purpose of the third experiment was to study the possible prophylactic action of pronethalol on epinephrine-induced ventricular arrhythmia.

After the second experiment one half hour was again allowed to elapse. The third experiment was commenced in the same manner as the previous two. This time, however, two milligrams of pronethalol were administered simultaneously with the commencement of the epinephrine infusion. The epinephrine infusion was maintained for the same two-minute period.

\section{Discussions of ResULTS}

During the 45- to 60-minute period of halothane-nitrous-oxide-oxygen anaesthesia, ventricular arrhythmia did not develop spontaneously in any of the dogs.

\section{First Experiment}

Arterial blood analysis after one hour of anaesthesia showed a fall in $\mathrm{pH}$ with normal carbon dioxide and oxygen tensions in all dogs.

With continuous epinephrine infusion, ventricular arrhythmias developed in all dogs (see Table I). The average time interval between commencement of the infusion and onset of arrhythmia was 40.8 seconds. Following the onset of the arrhythmias, epinephrine infusion was continued in seven dogs for an additional period of two minutes, and the arrhythmia persisted in all dogs throughout the 


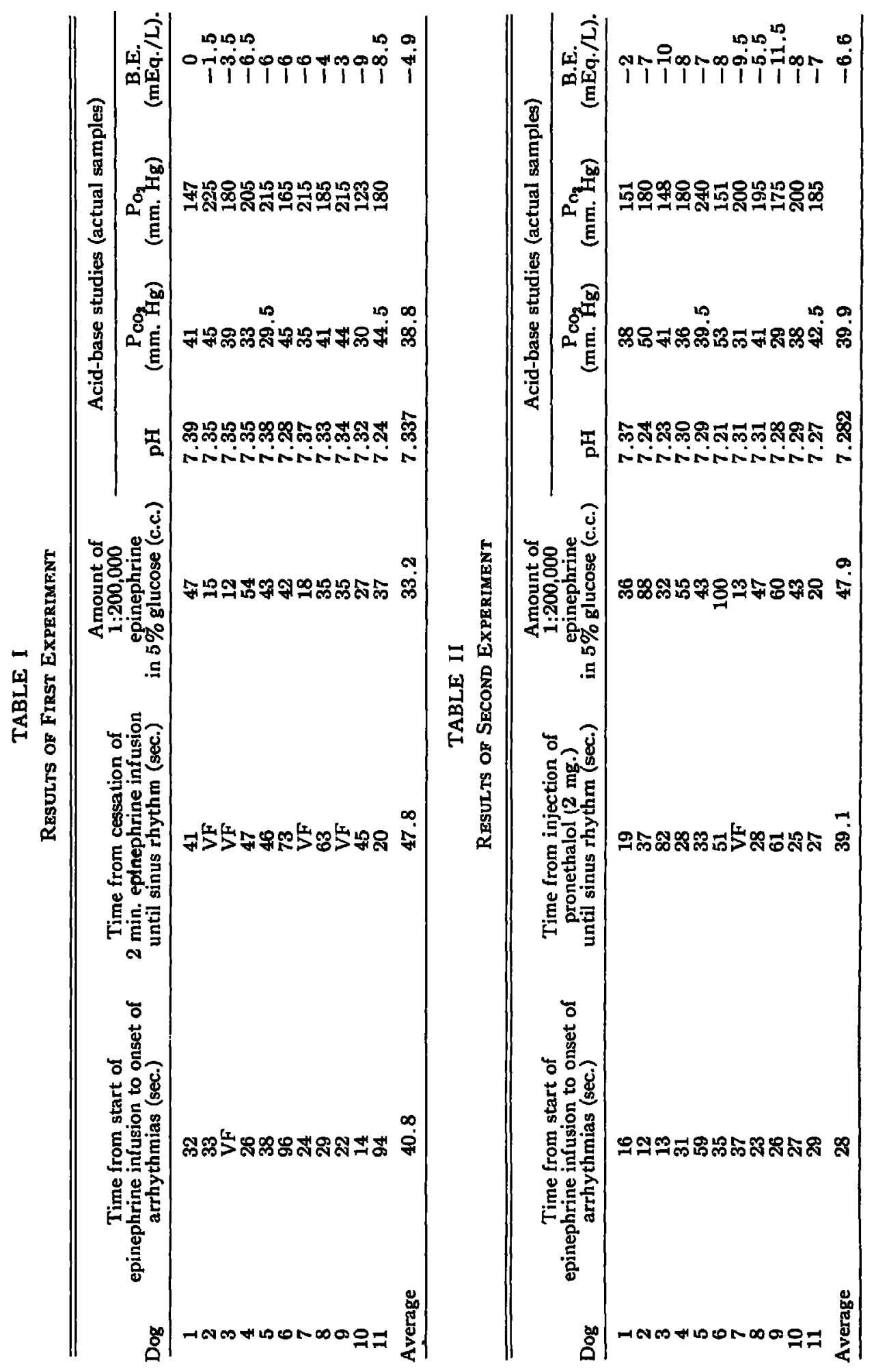


infusion. The epinephrine infusion was then stopped, and spontaneous reversion to sinus rhythm occurred in all seven dogs in an average time of 47.8 seconds.

In four dogs, however, with the onset of arrhythmia, ventricular fibrillation quickly supervened and resuscitative measures only were instituted.

This experiment showed that using the method outlined, each dog developed a ventricular arrhythmia. If the rate of epinephrine infusion was maintained, ventricular arrhythmia persisted. When the infusion was stopped after two minutes, spontaneous reversal to sinus rhythm occurred in each dog that did not fibrillate.

\section{Second Experiment}

Results on second blood samples showed an increasing degree of metabolic acidosis ( see Table II). This was probably due to the administration of epinephrine, and not to hypoxia, since arterial oxygen tensions were normal.

With the onset of an epinephrine-induced ventricular arrhythmia two milligrams of pronethalol were given intravenously, terminating the arrhythmias in ten of eleven dogs. The reversal of arrhythmias following pronethalol occurred in spite of continuous epinephrine infusion and in a shorter time (an average of 39.1 seconds) compared to the controls. Pronethalol was effective in suppressing epinephrine-induced ventricular arrhythmias during halothane anaesthesia, even in the presence of continuous epinephrine administration.

\section{Third Experiment}

The third blood sample showed more severe metabolic acidosis (see Table III). In spite of this, ventricular arrhythmias did not occur in any of the eleven dogs following simultaneous administration of epinephrine and two milligrams of pronethalol. It is well recognized that metabolic acidosis increases cardiac irritability and may lead to ventricular fibrillation. ${ }^{8}$

TABLE III

Results OF Third EXPERIMENT

\begin{tabular}{|c|c|c|c|c|c|}
\hline \multirow[b]{2}{*}{ Dog } & \multirow{2}{*}{$\begin{array}{c}\text { Amount of } \\
1: 200,000 \\
\text { epinephrine } \\
\text { in } 5 \% \text { glucose (c.c.) }\end{array}$} & \multicolumn{4}{|c|}{$\begin{array}{l}\text { Acid-base studies } \\
\text { (actual samples) }\end{array}$} \\
\hline & & $\mathrm{pH}$ & $\underset{(\mathrm{mm} . / \mathrm{Hg})}{\mathrm{P}_{\mathrm{H}}}$ & $\left.\stackrel{\mathrm{Po}_{\mathrm{g}}}{(\mathrm{mm} .} / \mathrm{Hg}\right)$ & $\underset{(\mathrm{mEq} \cdot / \mathrm{L} .)}{\text { B.E. }}$ \\
\hline $\begin{array}{r}1 \\
2 \\
3 \\
4 \\
5 \\
6 \\
7 \\
8 \\
9 \\
10 \\
11\end{array}$ & $\begin{array}{r}60 \\
50 \\
40 \\
47 \\
50 \\
100 \\
57 \\
50 \\
100 \\
27 \\
50\end{array}$ & $\begin{array}{l}7.36 \\
7.28 \\
7.25 \\
7.18 \\
7.28 \\
7.12 \\
7.24 \\
7.26 \\
7.21 \\
7.21 \\
7.18\end{array}$ & $\begin{array}{l}30 \\
30 \\
35.5 \\
47 \\
41 \\
69 \\
28 \\
44.5 \\
46 \\
40 \\
45\end{array}$ & $\begin{array}{l}142 \\
160 \\
160 \\
175 \\
270 \\
145 \\
140 \\
180 \\
147 \\
220 \\
151\end{array}$ & $\begin{array}{l}-7 \\
-11 \\
-11.5 \\
-11.5 \\
-7 \\
-9.5 \\
-13 \\
-7 \\
-10 \\
-11.5 \\
-11.5\end{array}$ \\
\hline Average & 58.1 & 7.224 & 38.7 & & -9.9 \\
\hline
\end{tabular}

NorE: No arrhythmias occurred during the two-minute period of infusion of epinephrine with simultaneous pronethalol. 
One dog developed ventricular fibrillation within 10 seconds following pronethalol administration and was successfully resuscitated. A probable explanation was the onset of ventricular fibrillation before the pronethalol could act.

The inhibition of ventricular arrhythmia in this third experiment may have been enhanced by the pronethalol administered during the second experiment, since there was an interval of only one half hour between the two doses.

Our observation of the suppression of ventricular arrhythmias in these studies was consistent with observations of Murray et al. (1963) and Somini and Lum (1964).

\section{SUMMARY}

Halothane anaesthesia was associated with mild metabolic acidosis which was increased after administration of epinephrine. Pronethalol was effective in preventing and suppressing epinephrine-induced ventricular arrhythmias during halothane anaesthesia, even in the presence of metabolic acidosis.

\section{RÉSUMÉ}

A la suite d'études préléminaires pour prouver que des arythmies ventriculaires peuvent être produites et soutenues par l'infusion d'épinéphrine au cours de l'anesthésie à l'halothane, les auteurs ont démontré, sur des chiens, que le pronethalol était efficace pour prévenir et supprimer cette sorte d'arythmie ventriculaire causée par l'infusion d'épinéphrine au cours de l'anesthésie a l'halothane, même en présence d'acidose métabolique.

\section{REFERENCES}

1. Ravantos, J. The Action of Fluothane and New Volatile Anaesthesia. Brit. J. Pharmacol. 11: 394 (1956).

2. Hall, Kennetri D. \& Norris, Forbes H., JR. Fluothane Sensitization of Dog Heart to Action of Epinephrine. Anaesthesiology. 19: 631 (1956).

3. Rogoman, E. P.; Jofnston, A. E.; \& Conn, A. W. The Use of Epinephrine during Halothane Annesthesia with Respect to Ventricular Irritability in Dogs. Anesth. \& Analg. 42: 109 (1963).

4. ANDERsen, N. \& Johansen, S. H. Incidence of Catechol-Amine-Induced Arrhythmias during Halothane Anesthesia. Anesthesiology. 24: 51 (1963).

5. Rosen, M. \& Ras, R. B. Adrenaline Infiltration during Halothane Anaesthesia: A Report of Two Cases of Cardiac Arrest. Brit. J. Anaesth. 35: 51 (1963).

6. Johnstone, M. \& Nisber, A. I. A. Ventricular Arrhythmias during Halothane Anaesthesia. Brit. J. Anaesth. 33: 9 (1961).

7. Johnstone, M. Adrenaline and Noradrenaline during Anaesthesia. Anaesthesia. 8: 32 (1953).

8. Genst, Paul H.; Fleming, WM. H.; \& Malm, James R. Relationship between Acidosis and Ventricular Fibrillation. Surg. Forum. 15: 242 (1964).

9. Murray, W. J.; McKniget, R. L.; \& Davis, D. A. Antagonism of Hydrocarbon AnaestheticEpinephrine Arrhythmias in Dogs by Nethalide, a Dichloroisoproterenol Analogue. Proc. Soc. Exper. Biol. \& Med. 113: 439 (1963). 